\title{
Scent-triggered navigation in honeybees
}

\section{Bees react to a perfume reminiscent of a distant food source by revisiting the site.}

T he honeybee, Apis mellifera, navigates rapidly and accurately to food sources that are often kilometres away ${ }^{1,2}$. They achieve this by learning visual cues, such as the location and colour of nectar-bearing flowers $^{1-3}$, and chemical cues, such as the scent and the taste of the nectar ${ }^{1,2}$. Here we train bees to visit differently scented sugar feeders placed at specific outdoor locations and find that they can be induced to visit the same locations simply by having the corresponding scent blown into the hive, even when the destinations no longer have the food or carry the scent. A familiar nectar scent can trigger specific memories of a route and therefore expedite navigation to the food source.

Von Frisch ${ }^{1}$ observed that a floral scent on a forager bee returning to the hive from a natural food source can induce other experienced foragers to revisit that source without communicating with each other by waggle dancing ${ }^{4}$. This and similar observations ${ }^{2,5-7}$ raise the question of what memories are triggered by scent. We now investigate this in an experiment designed to ensure that the bees do not just home in on a familiar scent ${ }^{1,2,5-7}$ and are not recruited by waggle dances.

We trained individually marked honeybees to visit two sugar feeders positioned at two different locations, each $50 \mathrm{~m}$ from the hive; the distance between the two locations was $30 \mathrm{~m}$. Each feeder carried a different scent, and feeders were offered alternately, switching every half hour. In the first experiment, scent one (offered at location one) was rose, and scent two (offered at location two) was lemon. After two days of training, the bees were tested periodically.

In the tests, the feeders were replaced by two empty, unscented jars. Scents one and two were blown into the hive, in turn, for 8 min each, by using a small fan attached to the hive entrance. During each scent-blowing interval, we noted the number of marked bees arriving at each test feeder. We also noted which feeder was visited first, the number of circlings (flights around the feeder), the number of landings on the feeder and the total number of visits (sum of all circlings and landings, including first visits). Tests were performed four times for each scent.

The trained bees that emerged from the hive upon injection of a scent showed a significant preference for the location that had carried the scent during training (Fig. 1). Injection of rose scent into the hive caused the trained bees to fly predominantly to location one. When lemon scent was blown into the hive, the overwhelming majority of trained bees visited location two. We repeated the

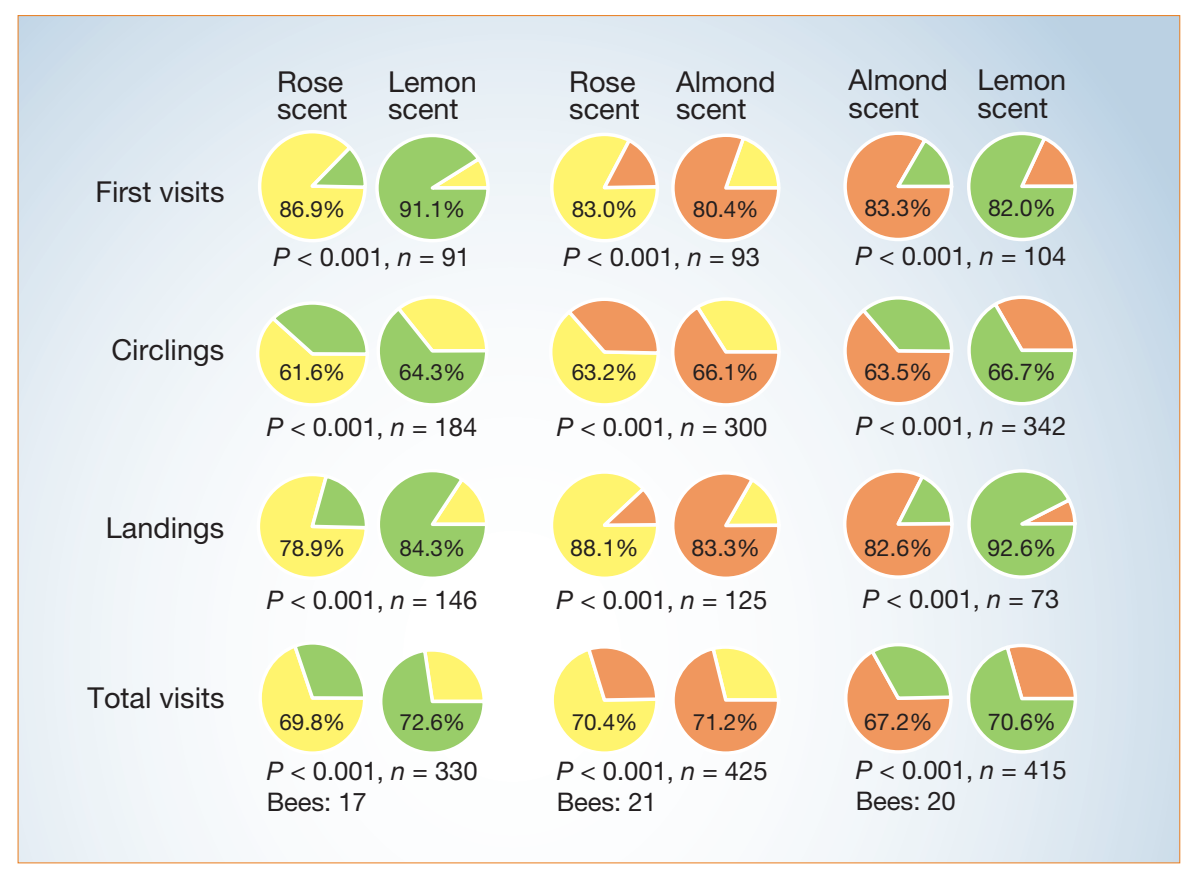

Figure 1 Scent association and foraging by honeybees. Three pairs of scent combinations were tested: rose and lemon, rose and almond, and almond and lemon. The proportion of first visits, circlings, landings and total visits to the two test feeders are shown. Colours indicate preferred feeder location: yellow, rose; green, lemon; orange, almond. The number of individually marked bees that visited both test feeders, the number of choices $(n)$ and the $P$-values ( $\chi^{2}$-test for choice frequencies) are shown at the bottom.

experiment with different pairs of scents: rose and almond (experiment two), and lemon and almond (experiment three). Each time we obtained similar results (Fig. 1). These findings indicate that each injected scent triggers visual memories of a specific location that the trained bees had previously visited.

Our test feeders were unscented, so the bees could not have found the correct site simply by homing in on the familiar scent, which is a well-known foraging strategy in bees $^{1,2,8}$. As the test feeders were empty, the arriving bees were not rewarded and so would not have danced upon return to the hive to recruit nestmates ${ }^{1,4}$. Bees arriving at the correct location must therefore have relied on previously acquired navigational memories evoked by the injected scent.

Our findings reveal that associative recall is a mechanism used by honeybees, in addition to the dance language ${ }^{1,4}$, to navigate successfully and repeatedly to an attractive food source. The taste and scent of nectar samples distributed by foragers on return to the hive ${ }^{1}$ could trigger recall of specific visual and route memories associated with the food site in experienced recruits. Recalling factors such as the distance and direction of the food source, the landmarks en route and at the destination, and the flower's colour and shape would speed up flight to the food site, enhancing the foraging efficiency of the colony.
Judith Reinhard, Mandyam V. Srinivasan, Shaowu Zhang

Visual Sciences, Research School of Biological Sciences, The Australian National University, GPO Box 475, Canberra, ACT 2601, Australia e-mail: reinhard@rsbs.anu.edu.au

1. von Frisch, K. The Dance Language and Orientation of Bee (Harvard Univ. Press, London, 1993).

2. Gould, J. L. in Insect Learning (eds Papaj, D. R. \& Lewis, A. C.) 18-50 (Chapman \& Hall, New York, 1993).

3. Wehner, R. in Handbook of Sensory Physiology (ed. Autrum, H.) 288-616 (Springer, Berlin, 1981)

4. Dyer, F. C. Annu. Rev. Entomol. 47, 917-949 (2002).

5. Ribbands, C. R. Proc. R. Entomol. Soc. A 29, 141-144 (1954). 6. Free, J. B. Nature 222, 778 (1969).

7. Jakobsen, H. B., Kristjansson, K., Rohde, B., Terkildsen, M. \& Olsen, C. E. J. Chem. Ecol. 21, 1635-1648 (1995).

8. Tautz, J. \& Sandeman, D. C. J. Comp. Physiol. A 189, 293-300 (2003).

Competing financial interests: declared none.

\section{Lifespan \\ Catch-up growth and obesity in male mice}

oor fetal growth is linked with longterm detrimental effects on health in adulthood ${ }^{1}$. Here we investigate whether the lifespan of male mice is affected by their growth rate when they were suckling and find that limiting growth during that period not only increases longevity but also protects against the life-shortening effect of an 


\begin{tabular}{|c|c|c|c|c|}
\hline Group & $\begin{array}{l}\text { Pregnancy diet } \\
\text { (\% protein) }\end{array}$ & $\begin{array}{l}\text { Lactation diet } \\
\text { (\% protein) }\end{array}$ & Weaning diet & $\begin{array}{c}\text { Average age at death } \\
\text { (days) }\end{array}$ \\
\hline Normal chow & 20 & 20 & Chow & $765 \pm 22$ \\
\hline Normal cafeteria & 20 & 20 & Cafeteria & $715 \pm 21$ \\
\hline Catch-up chow & 8 & 20 & Chow & $568 \pm 36$ \\
\hline Catch-up cafeteria & 8 & 20 & Cafeteria & $517 \pm 35$ \\
\hline Postnatal low-protein chow & 20 & 8 & Chow & $814 \pm 25$ \\
\hline Postnatal low-protein cafeteria & 20 & 8 & Cafeteria & $807 \pm 28$ \\
\hline
\end{tabular}

The different dietary regimes are summarized in the first three columns ( $n=24$ mice per group). Lifespans are expressed as mean \pm standard error and were analysed by two-way analysis of variance followed by Duncan's post-hoc testing where appropriate. Effect of early diet: $P<0.001$; effect of obesity, $P<0.01$.

obesity-inducing diet later on. By contrast, we find that lifespan is considerably shortened if the postnatal period of growth is accelerated to make up for reduced growth in utero, and that, in addition, these mice are susceptible to the adverse effects on longevity of an obesity-inducing diet after weaning.

We compared the longevity of male mice that had received poor nutrition during either their fetal or early postnatal life, and determined the additional impact of an obesity-inducing diet. We fed pregnant mice either a normal (containing $20 \%$ protein) or a low-protein $(8 \%)$ diet to restrict fetal growth. At birth, we cross-fostered pups so that the offspring of mothers fed on a lowprotein diet during pregnancy (litters culled to four pups to maximize nutrition and rate of catch-up growth during lactation) were suckled by normally fed dams ('catch-up' animals) ${ }^{2}$; the pups of mothers fed normally during pregnancy (unculled to minimize nutrition and growth during lactation) were suckled by dams fed on the low-protein diet ('postnatal low protein' animals) 2 . 'Normal' animals were the offspring of mothers fed on the 20\%-protein diet during both pregnancy and lactation.

At 21 days of age, half of the pups from each litter were weaned onto standard laboratory chow and the others onto an obesityinducing, 'cafeteria-style' $\operatorname{diet}^{3}$ (Table 1). This fattening diet contained $330 \mathrm{~g}$ standard laboratory chow, $330 \mathrm{~g} \mathrm{~kg}^{-1}$ full-fat sweetened condensed milk, $70 \mathrm{~g} \mathrm{~kg}^{-1}$ sucrose and $270 \mathrm{~g} \mathrm{~kg}^{-1}$ water. The diet is used as a model for human obesity that is based on excess energy consumption, because its high palatability reliably leads to obesity.

Mice that underwent fetal-growth restriction but which were cross-fostered at birth to normally fed dams experienced rapid catch-up growth and died at a younger age than controls $(P<0.001$; Table 1$)$. In contrast, mice that grew normally in utero but were nursed by low-protein-fed dams showed increased longevity $(P<0.01$; Table 1$)$. Subsequent consumption of the cafeteria-style, obesity-inducing diet reduced life expectancy in control mice by $7 \%(P<0.01)$ and in catch-up mice by $9 \%(P<0.05)$. However, the cafeteria-style diet had no effect on the longevity of mice whose growth was restricted during suckling (Table 1). The greatest difference in longevity was a $57 \%$ increase in lifespan $(P<0.001)$, which occurred between chow-fed, postnatally growthrestricted mice and catch-up mice fed on an obesity-inducing diet.

The mechanisms that underpin this large change in longevity are unclear. Reduced cell signalling by insulin-like peptides seems to increase the lifespan of nematodes, flies and mice $^{4}$, and is thought to protect against stresses such as oxidative damage ${ }^{4}$. Accelerated shortening of chromosomal telomeres, due to increased cell division and/or oxidative damage, may occur in the catch-up group of mice (as found in rats ${ }^{2}$ ) and could lead to cell senescence in critical organs such as the kidneys ${ }^{2,5,6}$.

We have shown that minor manipulation of maternal diet can increase life expectancy in mice by more than $50 \%$, a discovery that calls for attention to this aspect of growth and nutrition in humans. There is, after all, a significant difference between living to be 50 years old and reaching the age of 75 .

Susan E. Ozanne, C. Nicholas Hales

Department of Clinical Biochemistry, University of Cambridge, Cambridge CB2 2QR, UK

e-mail:seo10@cam.ac.uk

1. Hales, C. N. \& Barker, D. J. P. Br. Med. Bull. 60, 5-20 (2001).

2. Jennings, B. J., Ozanne, S. E., Dorling, M. W. \& Hales, C. N. FEBS Lett. 448, 4-8 (1999).

3. Petry, C. J., Ozanne, S. E., Wang, C. L. \& Hales, C. N. Clin. Sci. 93,147-152 (1997)

4. Tatar, M., Bartke, A. \& Antebi, A. Science 299, 1346-1351 (2003).

5. Johnson, P. R., Stern, J. S., Horwitz, B. A., Harris, R. E. \& Greene, S. F. Am. J. Clin. Nutr. 66, 890-903 (1997).

6. Wright, W. E. \& Shay, J. W. Nature Biotechnol. 20, 682-688 (2002).

Competing financial interests: declared none.

\section{Palaeogeography}

\section{Devonian tetrapod from western Europe}

S everal discoveries of Late Devonian tetrapods (limbed vertebrates) have been made during the past two decades $^{1-3}$, but each has been confined to one locality. Here we describe a tetrapod jaw of about 365 million years (Myr) old from the Famennian of Belgium, which is the first from western continental Europe. The jaw closely resembles that of Ichthyostega, a Famennian tetrapod hitherto known only from Greenland. The environment of this fossil provides information about the conditions that prevailed just before the virtual disappearance of tetrapods from the fossil record for $20 \mathrm{Myr}$.

The tetrapod jaw described here was found in the nineteenth century at Strud, Belgium, in the Evieux Formation, and was initially presumed to be from a fish ${ }^{4}$. It shows typical tetrapod characters in its bone ornamentation and chamfered ventral margin of the dentary ${ }^{5}$ (Fig. 1a). The teeth are widely spaced and strongly curved posteriorly (Fig. 1b), as in the corresponding jaw portion of Ichthyostega from Greenland ${ }^{6}$. Although the find cannot be referred with certainty to Ichthyostega, it is strong evidence for the existence of a close relative of this tetrapod genus outside Greenland.

The Evieux Formation (Upper Famennian; expansa conodont zone) consists of shale, arkosic and evaporitic dolomite beds accumulated within 5-8-metre-thick sequences. The environment was fluviatile to estuarine, and the uppermost part of the formation grades into a more marine environment with tempestite ${ }^{7,8}$. The sandstone surrounding the jaw is indicative of fluviatile conditions, as evidenced by a lack of grain sorting and by palaeosol fragments. This tetrapod therefore lived in rivers and estuaries, but the shoreline at the time of the Evieux Formation was oscillating south to north of Strud. The environment of the Devonian tetrapods seems to vary $^{2,3,9,10}$. For example, one genus was recovered from marine sequences ${ }^{2}$, whereas the Greenland tetrapods Ichthyostega and Acanthostega, found in massive red sandstone, lived in rivers ${ }^{9}$, far to the north of the Devonian shore.

The biogeographical distribution of Devonian tetrapods is near-global for the group ${ }^{3}$ but extremely restricted (to a single locality or small geographic area) at the generic level, which was presumably a result of the colonization of continental environments that were less favourable to wide dispersal than were marine ones. The occurrence of an Ichthyostega-like form in Belgium extends the geographical distribution for at least one taxon and suggests that they were not as restricted as previously thought. The Famennian river system of the Ardennes, Belgium, is assumed to originate from western Germany ${ }^{8}$ and, although both Belgium and Greenland were part of the Euramerican continent, they were separated by at least $1,500 \mathrm{~km}$.

The Late Devonian saw an increasing faunal exchange between Euramerica and Gondwana, leading to a loss of faunal regionalism. The rapid spread of tetrapods from a probable Euramerican cradle ${ }^{6}$ forms part of this picture, as does the arrival in Euramerica of fish groups of Gondwanan origin (notably the gyracanthid acanthodians and the lobefinned rhizodonts and megalichthyids). 